\title{
Evaluation of Antidiabetic Activity of the Leaf Latex of Aloe pulcherrima Gilbert and Sebsebe (Aloaceae)
}

\author{
Gedefaw Getnet Amare $(D$, Birhanu Geta Meharie, and Yaschilal Muche Belayneh \\ Department of Pharmacy, College of Medicine and Health Sciences, Wollo University, Dessie, Ethiopia \\ Correspondence should be addressed to Gedefaw Getnet Amare; gedefawg39@gmail.com
}

Received 26 August 2020; Revised 15 September 2020; Accepted 19 September 2020; Published 5 October 2020

Academic Editor: José Roberto Santin

Copyright $\odot 2020$ Gedefaw Getnet Amare et al. This is an open access article distributed under the Creative Commons Attribution License, which permits unrestricted use, distribution, and reproduction in any medium, provided the original work is properly cited.

\begin{abstract}
The leaf latex of Aloe pulcherrima has been used as remedy for diabetes mellitus. This was carried out to determine in vitro and in vivo antidiabetic activities of the leaf latex of Aloe pulcherrima. Methods. Sucrase and maltase inhibitory activity of the leaf latex of A. pulcherrima was determined in glucose oxidase assay, and $\alpha$-amylase inhibitory activity was determined in dinitrosalicylic acid assay. Normoglycemic, glucose-loaded, and streptozotocin-induced diabetic mice were treated orally to determine blood glucose lowering activity of the latex. Effect of the latex on serum lipid level and body weight was measured in streptozotocin-induced diabetic mice. Additionally, DPPH assay was used to determine free radical scavenging capacity of the latex. Results. Antioxidant activity of the latex was concentration dependent; the strongest inhibition was measured at $800 \mu \mathrm{g} / \mathrm{ml}(80.57 \%)$. The leaf latex of A. pulcherrima inhibited sucrase $\left(\mathrm{IC}_{50}=2.92 \mu \mathrm{g} / \mathrm{ml}\right)$, maltase $\left(\mathrm{IC}_{50}=11.81 \mu \mathrm{g} / \mathrm{ml}\right)$ and $\alpha$-amylase $\left(\mathrm{IC}_{50}=14.92 \mu \mathrm{g} / \mathrm{ml}\right)$ enzymes. All doses of the leaf latex induced hypoglycemic effect after $4 \mathrm{~h}$ in normal mice, and low dose of the latex did not show significant effect after $6 \mathrm{~h}$. Glucose reduction of the leaf latex of A. pulcherrima was significant $(p<0.05)$ in oral glucose-loaded mice compared to the vehicle control. Blood glucose level of diabetic mice was significantly $(p<0.05)$ reduced on week one and weak two in a streptozotocin-induced diabetic mouse model. Glucose reduction increased with increasing the doses of the leaf latex of A. pulcherrima on week one ( $p<0.05(200 \mathrm{mg} / \mathrm{kg}), p<0.01(400 \mathrm{mg} / \mathrm{kg})$, and $p<0.001(600 \mathrm{mg} / \mathrm{kg}))$. Administration of the leaf latex of $A$. pulcherrima for two weeks significantly $(p<0.05)$ improved diabetic dyslipidemia and body weight of diabetic mice. Conclusion. The study confirmed that the leaf latex of the plant showed a significant antidiabetic activity justifying the traditional uses of the plant.
\end{abstract}

\section{Background}

Herbal therapies are proven safe and effective for healing diseases and have been the potential source for the development of new drugs [1,2]. A majority of people in the world rely on herbal therapy $[1,3]$. Phytotherapy is the antecedent of modern drugs, and one-third of the topselling drugs in the world are plant origins $[4,5]$. More than 800 plants have been used as remedies for diabetes healing, and the most successful story in drug discovery is isolation of guanidines (analogue of metformin) from Galega officinalis $[2,6]$. A variety of phytochemicals such as flavonoids, phenols, triterpenoids, and alkaloids have shown prominent antidiabetic activity $[2,7,8]$. The leaf of Capparis spinosa L. and Juglans regia L. contained phenols and flavonoids (rutin) that showed prominent antidiabetic and antidyslipidemic activity $[9,10]$. Rutin showed strong free radical scavenging and cholinesterase inhibitory activity and reverse kidney and liver injuries $[10,11]$. The leaf gel of Aloe vera offers promising results for the development of novel antidiabetic drugs. The leaf gel of this plant has been under clinical trial in prediabetic and type 2 diabetic patients $[12,13]$. Combination of deleterious effects, limited efficacy, and contraindication of current antidiabetic drugs initiate noble antidiabetic drug development to minimize DM progression and deleterious effects [14-16].

Aloe pulcherrima, which belongs to Aloaceae plant family, is an Ethiopian endemic plant. The plant shows U-shaped peduncle in its flowers (Figure 1) [17]. Many 


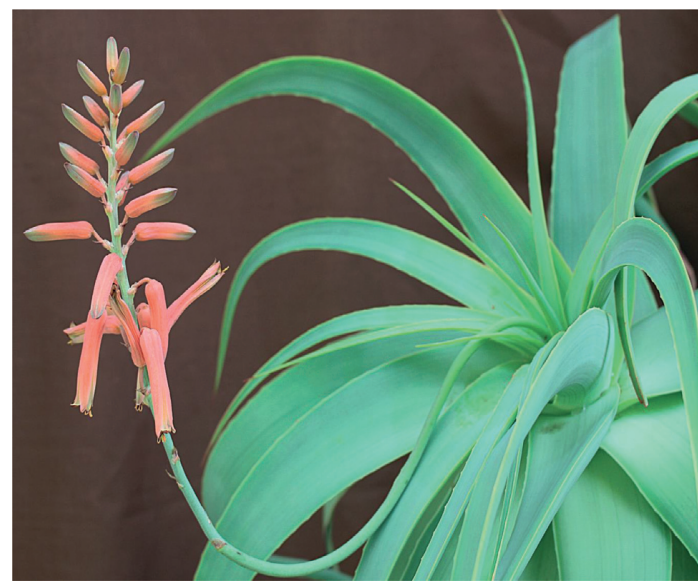

Figure 1: Picture of Aloe pulcherrima.

compounds including chrysophanol, aloesaponarin, nataloin, and 7-hydroxyaloin were isolated from the plant and showed antibacterial, antifungal, and antimalarial effects $[18,19]$. The leaf latex of Aloe pulcherrima was found to be safe up to $5000 \mathrm{mg} / \mathrm{kg}$ in mice [18]. The leaf latex of the plant has been used in folk medicine to treat diabetes mellitus without scientific studies [20, 21]. Therefore, the current study was conducted to investigate antidiabetic activity of the leaf latex of plant.

\section{Methods}

2.1. Chemicals. Ascorbic acid (99\%, Japan), dinitrosalicylic acid, phenol, $\mathrm{Na}_{2} \mathrm{SO}_{3}$, sodium hydroxide, potassium sodium tartrate, phosphate, sucrose, maltose, intestinal acetone powder, DPPH (97\%, Tokyo, Japan), citric acid monohydrate, and trisodium citrate dihydrate were used during the study.

2.2. Preparation of the Leaf Latex of Aloe pulcherrima. The leaf of Aloe pulcherrima Gilbert and Sebsebe was collected from Fiche (located in Oromia Region, Central Ethiopia) in December, 2019. The plant was identified by Professor Sebsebe Demisew (botanist), and the specimen was deposited in the National Herbarium of Addis Ababa University (AAU) with the voucher number of SD009/19. The leaf of Aloe pulcherrima was cut transversely close to the stem, and then, the leaf was inclined towards the collecting plate to obtain yellowish exudate. The latex was dried under shade at room temperature with optimal ventilation. The dried latex was crushed into powder by mortar and pestle and stored in vial until used for the experiment.

2.3. Experimental Mice. Male Swiss albino mice (weighing 25-35 grams and 2-3 months of age) were purchased from EPHI and used in the study. Mice were maintained at $12 \mathrm{~h}$ light/dark cycle and were allowed free to standard pellet diet and water ad libitum.
2.4. Phytochemical Analysis of the Leaf Latex of Aloe pulcherrima. Qualitative preliminary phytochemical screening tests were carried out for the dried latex of Aloe pulcherrima as per the standard methods to analyze the presence or absence of secondary metabolites [22, 23].

2.5. Antioxidant Activity of the Leaf Latex of Aloe pulcherrima. Antioxidant capacity of the latex was evaluated in $\mathrm{DPPH}$ assay as described in the literature with some modifications [24]. Three milliliters of $0.1 \mathrm{mM}$ ( $4 \mathrm{mg} / 100 \mathrm{ml}$ solution) was mixed with one milliliter of methanolic solution of different concentrations $(25-800 \mu \mathrm{g} / \mathrm{ml})$ of the latex. Ascorbic acid with the same concentration was served as the positive control, and $4 \mathrm{ml}$ solution of the free radical (DPPH) without the latex was used as the vehicle control. After 30-minute incubation, the absorbance of test solutions and the control were read at $517 \mathrm{~nm}$ via a UV spectrophotometer. Percentage was calculated by the following formula:

$$
\% \text { of free radical inhibition }=\frac{\left(A_{0}-A_{1}\right)}{A_{0}} \times 100,
$$

where $A_{0}$ is absorbance of the control and $A_{1}$ is absorbance of the extract/standard.

2.6. Enzyme Inhibitory Measurement. The $\alpha$-amylase inhibitory assay of the leaf latex of $A$. pulcherrima was determined as mentioned in the literature studies with few modifications [24-26]. Ten $\mu$ l latex solution $(15.6-500 \mu \mathrm{g} /$ $\mathrm{ml})$ was incubated in $75 \mu \mathrm{l}$ porcine pancreatic $\alpha$-amylase

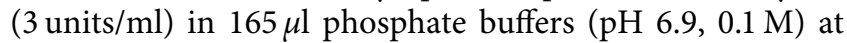
$37^{\circ} \mathrm{C}$ for 15 minutes. A volume of $100 \mu \mathrm{l}$ starch solution ( $1 \mathrm{~g} /$ L) in buffer was added to the reaction mixture and incubated at $37^{\circ} \mathrm{C}$ for $20 \mathrm{~min}$. The reaction was ceased by adding $250 \mathrm{ml}$ dinitrosalicylic acid (1\%) and boiled in water bath for ten minute at $100^{\circ} \mathrm{C}$. Then, $250 \mu \mathrm{l}$ potassium sodium tartrate (40\%) was added into the mixtures. Acarbose was served as a positive control, and $\mathrm{IC}_{50}$ was determined. The mixtures were kept on cold water bath at room temperature, and the absorbance was read at $540 \mathrm{~nm}$ by using by a UV spectrometer:

$$
\% \text { of free radical inhibition }=\frac{(A-B)}{A} \times 100,
$$

where $A$ is the absorbance of the control and $B$ is the absorbance of the latex/standard.

The sucrase and maltase inhibitory assays of the leaf latex were determined by the glucose oxidase method [26]. Acetone solution (100 mg in $3 \mathrm{ml}$ normal saline) was centrifuged at $12,000 \mathrm{rpm}$ for thirty minutes. A volume of $30 \mu \mathrm{l}$ sucrase and $10 \mu \mathrm{l}$ maltase solutions was incubated in $40 \mu \mathrm{l}$ sucrose $(400 \mathrm{mM})$ and $30 \mu \mathrm{l}$ maltose $(86 \mathrm{mM})$ solutions, respectively. Ten $\mu \mathrm{l}$ latex solution $(15.6-500 \mu \mathrm{g} / \mathrm{ml})$ and then $0.1 \mathrm{M}$ phosphate buffer $(\mathrm{pH}=6.9)$ were added to maintain the $100 \mu \mathrm{l}$ final volume and incubated for $1 \mathrm{hr}$ at $37^{\circ} \mathrm{C}$. Then, the mixtures were suspended in boiling water for ten minutes to cease the reaction. The absorbance of glucose which was released from the reaction was read at $450 \mathrm{~nm}$ by 
the glucose oxidase method. Sucrase and maltase inhibitory activities were represented as $\%$ inhibition:

$$
\% \text { inhibition }=\frac{(A-B)}{A} \times 100,
$$

where $A$ is the absorbance of the control and $B$ is the absorbance of the samples.

2.7. Grouping and Dosing of Animals. Male mice were used in the normoglycemic, oral glucose tolerance test (OGTT) and streptozotocin-induced diabetic model since female mice have low survival, insensitive to STZ and insulin [27-29]. In normoglycemic and OGTT, mice were randomly divided into five groups $(n=6)$. Groups 1 and 2 (negative and positive control) were treated with $10 \mathrm{mg} / \mathrm{kg}$ vehicle $(2 \%$ tween 80 in distilled water) and $5 \mathrm{mg} / \mathrm{kg}$ glibenclamide (Julphar), respectively; groups 3, 4, and 5 were given 200,400, and $600 \mathrm{mg} / \mathrm{kg}$ of the leaf latex. In the STZ-induced diabetic model, mice were randomly divided into six groups (5 diabetic groups and 1 nondiabetic group, $n=6$ ) [30]. Groups 1 and 2 (normal and diabetic control) were given the vehicle, and group 3 was treated with standard drug. Groups 4, 5, and 6 (diabetic test groups) were treated with 200, 400, and $600 \mathrm{mg} / \mathrm{kg}$ of the leaf latex.

2.8. Induction of Experimental Diabetes. Experimental diabetes was induced by intraperitoneal injection of streptozotocin at the dose of $150 \mathrm{mg} / \mathrm{kg}$ on $16 \mathrm{~h}$ fasted mice [30,31]. After thirty-minute STZ injection, mice were allowed free to food and water. After six hours, mice were allowed ad libitum glucose solution (5\%) for one day to prevent hypoglycemic shock and death. After three days of streptozotocin administration, mice with fasting BGL $>200 \mathrm{mg} / \mathrm{dl}$ were candidate for the experiment [27, 31-33].

\subsection{Evaluation of the Effect of the Leaf Latex in Normoglycemic} Model. Sixteen-hour fasted normal mice were treated orally with vehicle, standard drug, and different doses of the leaf latex according to their respective groups as mentioned above. Blood was measured from the tail vein of the mice by using a glucometer with strip to determine the glucose level before treatment and at $1,2,4$, and $6 \mathrm{~h}$ after treatment $[27,34]$.

2.10. Evaluation of the Effect of the Leaf Latex on Oral Glucose Tolerance Test (OGTT). The oral glucose tolerance test was done in sixteen-hour fasted mice to evaluate antihyperglycemic potential of the leaf latex of A. pulcherrima $[30,35,36]$. Fasted mice were treated with the vehicle, glibenclamide, and the three different doses of the latex according to their groups. After thirty minutes, oral glucose solution (40\%) at the dose of $2 \mathrm{~g} / \mathrm{kg}$ was given to the mice. Then, blood was withdrawn from the tail vein of each mouse to determine the glucose level at $0 \mathrm{~h}$ (before glucose administration) and at $0.5,1$, and $2 \mathrm{~h}$ after glucose administration $[27,30,31]$.
2.11. Evaluation of the Effects of the Leaf Latex on Blood Glucose, Body Weight, and Plasma Lipid Level of STZ-Induced Diabetic Mice. After 3 days of streptozotocin administration, normal and diabetic mice were randomly assigned to different groups and then BGL and body weight of the mice were measured. Then, mice were treated with the vehicle, standard drug, and the latex daily for two weeks. On weeks one and two, BGL and body weight of 16-hour fasted mice were recorded [31,37]. On day 15 , overnight fasted mice were sacrificed using high-dose pentobarbitone $(150 \mathrm{mg} / \mathrm{kg}$, i.p.) and then blood samples were collected from each mouse in a sterile tube. Blood samples were allowed to coagulate for two hours at room temperature, then centrifuged at $2000 \mathrm{rpm}$ for ten minutes. Then, serum samples were prepared by decanting the supernatant into test tubes to determine the level of TC, TG, and HDL-C.

2.12. Experimental Animal Sacrification (Euthanasia). Diabetic mice were sacrificed at the end of the experiment by using a high-dose anesthetic agent. Each mouse was anesthetized by pentobarbitone at the dose of $150 \mathrm{mg} / \mathrm{kg}$ intraperitoneally [38].

2.13. Statistical Analysis. The results of the study were expressed as mean \pm standard error of the mean. Statistical analysis of the data was carried out with one-way analysis of variance followed by the Tukey post hoc multiple comparison test. Significant differences were set at $p$ values lower than 0.05 .

\section{Results}

3.1. Phytochemical Analysis of the Leaf Latex of Aloe pulcherrima. In this study, preliminary phytochemical analysis indicated the presence of the following secondary metabolites in the leaf latex of the plant (Table 1).

\subsection{Antioxidant Activity of the Leaf Latex of Aloe pulcherrima.} The leaf latex of A. pulcherrima showed concentrationdependent antioxidant activity in DPPH assay (Figure 2). The finding showed that the color of tested solution was changed from violet to slight yellow depending on the concentration. The latex was endowed with antioxidant activity, and $50 \%$ inhibitory concentration $\left(\mathrm{IC}_{50}\right.$ ) was found to be $9.36 \mu \mathrm{g} / \mathrm{ml}(p<0.001)$.

\subsection{The Inhibitory Effect of the Leaf Latex of Aloe pulcherrima} on Sucrase, Maltase, and $\alpha$-Amylase Enzymes. Enzyme inhibition assay showed that the latex possessed an inhibitory effect on sucrase, maltase and $\alpha$-amylase enzymes (Figure 3). Even though all enzymes were inhibited by the latex, greater inhibition was shown on sucrase $\left(\mathrm{IC}_{50}=2.92 \mu \mathrm{g} / \mathrm{ml}\right)$ than maltase $\left(\mathrm{IC}_{50}=11.81 \mu \mathrm{g} / \mathrm{ml}\right)$ and $\alpha$-amylase $\left(\mathrm{IC}_{50}=14.92 \mu \mathrm{g} /\right.$ $\mathrm{ml}$ ) enzymes. The finding of the study showed that sucrase, maltase, and $\alpha$-amylase inhibition capacity of the latex was concentration dependent. Percentage inhibition of the latex was significant $(p<0.001)$ compared to vehicle control. 
TABLe 1: Phytochemical analysis result.

\begin{tabular}{lc}
\hline Phytochemical constituents & Result \\
\hline Anthraquinones & + \\
Flavonoids & + \\
Saponins & + \\
Glycosides & + \\
Tannins & + \\
Phenols & + \\
Alkaloids & + \\
Steroids & - \\
\hline
\end{tabular}

Abbreviation: +, present; -, absent.

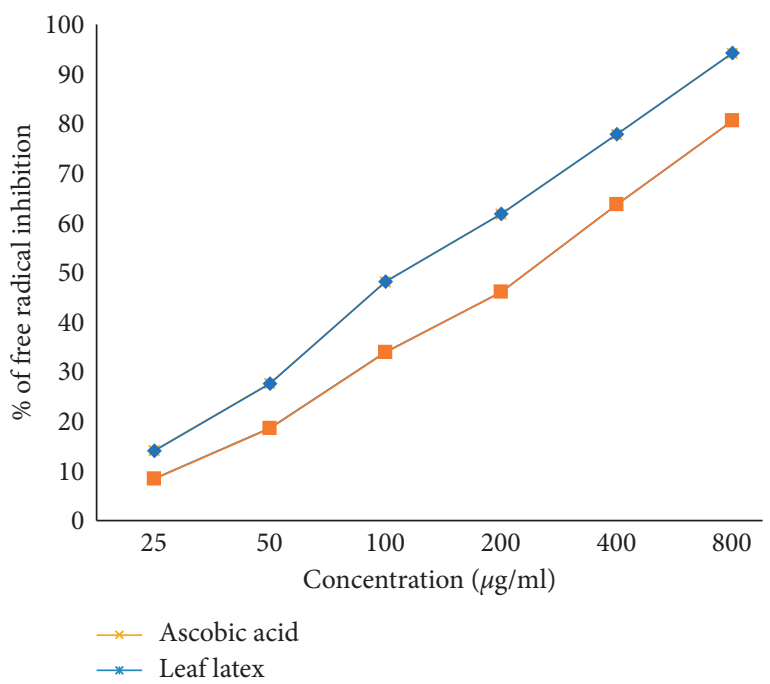

Figure 2: Percentage of free radical inhibition activity of the leaf latex of $A$. pulcherrima.

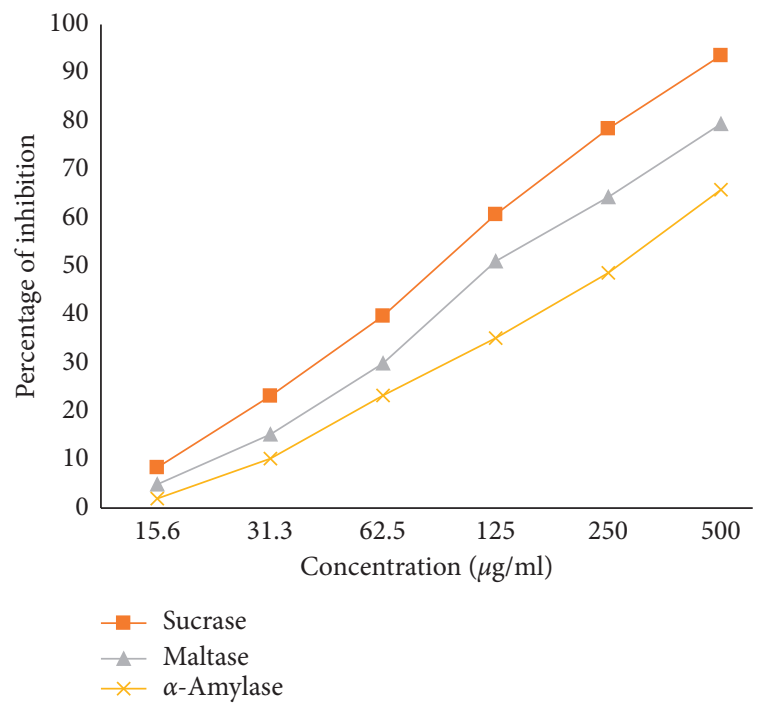

Figure 3: The effect of the leaf latex of Aloe pulcherrima on sucrase, maltase, and $\alpha$-amylase enzymes.

3.4. The Effect of the Leaf Latex of Aloe pulcherrima on Glucose Level in Normoglycemic Mice. Four hours after administration of the latex, all doses showed significant $(p<0.05)$ hypoglycemic effect compared to vehicle control (Table 2 ).
After $6 \mathrm{~h}$, hypoglycemic effect of 400 and $600 \mathrm{mg} / \mathrm{kg}$ dose was significant $(p<0.01)$ in normal mice but $200 \mathrm{mg} / \mathrm{kg}$ of the latex did not show hypoglycemic effect at $6^{\text {th }} \mathrm{h}$ after treatment. In addition, glibenclamide $(5 \mathrm{mg} / \mathrm{kg})$ produced significant effect (hypoglycemia) at $2(p<0.01), 4(p<0.01)$, and $6 \mathrm{~h}(p<0.001)$ compared to the vehicle control.

3.5. Effect of the Leaf Latex of A. pulcherrima on Glucose Tolerance Test in Mice. Mean BGL of all groups was not significantly different from each other at zero and thirty minutes after glucose feeding (Table 3). Peak blood glucose level was measured after thirty minutes. Blood glucose reduction was significant $(p<0.001)$ at 1 and 2 hours with 400 and $600 \mathrm{mg} / \mathrm{kg}$ of the leaf latex compared to the vehicle. Blood glucose reduction at $200 \mathrm{mg} / \mathrm{kg}$ dose of the latex was delayed and found to be significant $(p<0.01)$ after 2 hours.

3.6. Effect of the Latex of A. pulcherrima on Blood Glucose Level of STZ-Induced Diabetic Mice. Dose-dependent blood glucose reduction was measured in the mice treated with all doses of the latex on week one and week two compared to diabetic control. Glucose level of the mice treated with the latex at $200 \mathrm{mg} / \mathrm{kg}$ was significantly $(p<0.05$ on week 1 ; $p<0.01$ on week 2) changed compared to diabetic control, but glucose reduction was significantly $(p<0.05)$ lower than $5 \mathrm{mg} / \mathrm{kg}$ glibenclamide (Table 4 ). Blood glucose reduction with $400 \mathrm{mg} / \mathrm{kg}(p<0.01$ on week $1 ; p<0.001$ on week 2$)$ and $600 \mathrm{mg} / \mathrm{kg}(p<0.001$ on both weeks) of the latex was significant compared to the vehicle control.

3.7. Effect of the LeafLatex of Aloe pulcherrima on Body Weight of STZ-Induced Diabetic Mice. Significant body weight loss was measured in diabetic control compared to the mice treated with all doses of the latex and glibenclamide. The three doses of the latex significantly $(p<0.01)$ improved body weight of the mice on weeks one and two compared to vehicle control (Table 5). There was no significant body weight variation within latex- and glibenclamide-treated groups.

3.8. Effect of the Leaf Latex of Aloe pulcherrima on Serum Lipid Level in Diabetic Mice. Serum level of TC and TG was significantly $(p<0.001)$ elevated, and HDL-C was significantly $(p<0.001)$ declined in the diabetic control compared to the normal control (Table 6). Administration of the latex for two weeks significantly $(p<0.05$ at $200 \mathrm{mg} / \mathrm{kg}$ and $p<0.01$ at 400 and $600 \mathrm{mg} / \mathrm{kg}$ ) reduced level of TC and TG and increased $(p<0.01)$ the level of HDL-C in diabetic mice. Total cholesterol and triglyceride reducing effect of the latex at $200 \mathrm{mg} / \mathrm{kg}$ dose was lower than $5 \mathrm{mg} / \mathrm{kg}$ glibenclamide $(p<0.001)$.

\section{Discussion}

Antidiabetic activity of the leaf latex of Aloe pulcherrima was evaluated in vitro and in vivo models that offer useful evidence for the development of novel plant-based antidiabetic drugs $[2,6,24]$. 
TABLE 2: The effect of the leaf latex of Aloe pulcherrima on glucose level in normoglycemic mice.

\begin{tabular}{|c|c|c|c|c|c|}
\hline \multirow{2}{*}{ Groups } & \multicolumn{5}{|c|}{ Blood glucose level (mg/dl) } \\
\hline & 0 & $1 \mathrm{~h}$ & $2 \mathrm{~h}$ & $4 \mathrm{~h}$ & $6 \mathrm{~h}$ \\
\hline $10 \mathrm{ml} / \mathrm{kg}$ vehicle & $90.26 \pm 0.31$ & $86.29 \pm 0.75$ & $78.72 \pm 1.18$ & $74.82 \pm 1.71$ & $74.46 \pm 1.03$ \\
\hline $5 \mathrm{mg} / \mathrm{kg} \cdot \mathrm{GB}$ & $90.25 \pm 0.25$ & $79.62 \pm 0.11$ & $64.89 \pm 0.16^{\mathrm{a} 2}$ & $61.09 \pm 0.29^{\mathrm{a} 2}$ & $55.75 \pm 2.09^{\mathrm{a} 3}$ \\
\hline $200 \mathrm{mg} / \mathrm{kg} \cdot \mathrm{LL}$ & $89.33 \pm 0.95$ & $82.61 \pm 1.42$ & $76.78 \pm 1.34$ & $68.03 \pm 1.33^{\mathrm{a} 1}$ & $72.49 \pm 1.49$ \\
\hline $400 \mathrm{mg} / \mathrm{kg} \cdot \mathrm{LL}$ & $89.43 \pm 0.15$ & $81.49 \pm 0.96$ & $76.19 \pm 1.41$ & $67.57 \pm 2.17^{\mathrm{a} 1}$ & $62.65 \pm 1.03^{\mathrm{a} 2}$ \\
\hline $600 \mathrm{mg} / \mathrm{kg} \cdot \mathrm{LL}$ & $91.11 \pm 0.34$ & $80.61 \pm 0.46$ & $74.22 \pm 1.09$ & $67.12 \pm 0.85^{\mathrm{a} 1}$ & $61.11 \pm 0.69^{\mathrm{a} 2}$ \\
\hline
\end{tabular}

The result is expressed as mean \pm standard error of the mean, $n=6$; ${ }^{\mathrm{a}}$ compared to vehicle; ${ }^{1} p<0.05 ;{ }^{2} p<0.01 ;{ }^{3} p<0.001$; GB, glibenclamide; LL, leaf latex.

TABLe 3: Effect of the leaf latex of A. pulcherrima on the glucose tolerance test in mice.

\begin{tabular}{lcccc}
\hline \multirow{2}{*}{ Groups } & \multicolumn{4}{c}{ Blood glucose level $(\mathrm{mg} / \mathrm{dl})$} \\
& $0 \mathrm{~h}$ & $0.5 \mathrm{~h}$ & $1 \mathrm{~h}$ & $2 \mathrm{~h}$ \\
\hline $10 \mathrm{ml} / \mathrm{kg}$ vehicle & $89.13 \pm 0.31$ & $156.95 \pm 0.67$ & $142.85 \pm 0.55$ & $125.51 \pm 0.81$ \\
$5 \mathrm{mg} / \mathrm{kg}$ glibenclamide & $88.37 \pm 1.19$ & $157.23 \pm 0.71$ & $114.68 \pm 1.33^{\mathrm{a} 3}$ & $91.47 \pm 0.27^{\mathrm{a} 3}$ \\
$200 \mathrm{mg} / \mathrm{kg} \cdot \mathrm{LL}$ & $89.33 \pm 0.45$ & $158.24 \pm 1.31$ & $129.57 \pm 0.61$ & $107.50 \pm 1.09^{\mathrm{a} 2}$ \\
$400 \mathrm{mg} / \mathrm{kg} \cdot \mathrm{LL}$ & $87.67 \pm 0.26$ & $159.12 \pm 0.29$ & $120.28 \pm 0.72^{\mathrm{a} 3}$ & $98.61 \pm 0.37^{\mathrm{a} 3}$ \\
$600 \mathrm{mg} / \mathrm{kg} \cdot \mathrm{LL}$ & $90.21 \pm 1.22$ & $157.87 \pm 0.51$ & $118.25 \pm 0.27^{\mathrm{a} 3}$ & $94.72 \pm 0.51^{\mathrm{a} 3}$ \\
\hline
\end{tabular}

The result is presented as mean \pm standard error of the mean, $n=6$; ${ }^{a}$ compared to vehicle; ${ }^{1} p<0.01 ;{ }^{2} p<0.001$; LL, leaf latex.

TAвLe 4: The effect of the leaf latex of Aloe pulcherrima on glucose level in diabetic mice.

\begin{tabular}{|c|c|c|c|}
\hline \multirow{2}{*}{ Groups } & \multicolumn{3}{|c|}{ Blood glucose level (mg/dl) } \\
\hline & Pretreatment & Week one & Week two \\
\hline $10 \mathrm{ml} / \mathrm{kg}$ vehicle $\mathrm{NC}$ & $89.17 \pm 1.56$ & $88.86 \pm 1.89$ & $90.56 \pm 1.35$ \\
\hline $10 \mathrm{ml} / \mathrm{kg}$ vehicle $\mathrm{DC}$ & $258.47 \pm 1.39$ & $262.62 \pm 1.09$ & $263.75 \pm 4.23$ \\
\hline $5 \mathrm{mg} / \mathrm{kg}$ glibenclamide & $260.56 \pm 3.37$ & $240.17 \pm 2.50$ a3b1 & $233.33 \pm 1.89^{\text {a3b } 1}$ \\
\hline $200 \mathrm{mg} / \mathrm{kg} \cdot \mathrm{LL}$ & $259.33 \pm 2.43$ & $248.47 \pm 2.44^{\mathrm{alcl}}$ & $241.27 \pm 1.96^{\mathrm{a} 2 \mathrm{c} 1}$ \\
\hline $400 \mathrm{mg} / \mathrm{kg} \cdot \mathrm{LL}$ & $261.49 \pm 2.98$ & $247.28 \pm 2.99^{\mathrm{a} 2}$ & $237.15 \pm 4.09^{\mathrm{a} 3}$ \\
\hline $600 \mathrm{mg} / \mathrm{kg} \cdot \mathrm{LL}$ & $259.89 \pm 2.50$ & $245.45 \pm 2.50^{\mathrm{a} 3 \mathrm{~b} 1}$ & $234.21 \pm 0.72^{\mathrm{a} 3}$ \\
\hline
\end{tabular}

The result is expressed as mean \pm standard error of the mean, $n=6$; ${ }^{\text {a }}$ compared to diabetic control; ${ }^{b}$ to $200 \mathrm{mg} / \mathrm{kg}$; ${ }^{c}$ to $5 \mathrm{mg} / \mathrm{kg}$ glibenclamide; ${ }^{1} p<0.05$; ${ }^{2} p<0.01 ;{ }^{3} p<0.001$. DC, diabetic control; LL, leaf latex; NC, normal control.

TABLE 5: The effect of the latex of Aloe pulcherrima on body weight of diabetic mice.

\begin{tabular}{lccc}
\hline Groups & & $\begin{array}{l}\text { BW (gram) } \\
\text { Week one }\end{array}$ & Week two \\
\hline $10 \mathrm{ml} / \mathrm{kg}$ vehicle & $27.82 \pm 0.32$ & $28.64 \pm 0.38$ & $28.94 \pm 0.38$ \\
$\mathrm{NC}$ & & & \\
$10 \mathrm{ml} / \mathrm{kg}$ vehicle & $24.59 \pm 0.59$ & $23.08 \pm 0.74$ & $22.94 \pm 0.45$ \\
$\mathrm{DC}$ & & & \\
$5 \mathrm{mg} / \mathrm{kg}$ & $24.23 \pm 0.53$ & $28.76 \pm 0.56^{\mathrm{a} 3}$ & $28.87 \pm 0.36^{\text {a3 }}$ \\
glibenclamide & $23.19 \pm 0.65$ & $26.65 \pm 0.49^{\text {al }}$ & $26.15 \pm 0.43^{\text {a1 }}$ \\
$200 \mathrm{mg} / \mathrm{kg} \cdot \mathrm{LL}$ & $23.47 \pm 0.63$ & $26.91 \pm 0.60^{\text {al }}$ & $27.23 \pm 0.61^{\text {a1 }}$ \\
$400 \mathrm{mg} / \mathrm{kg} \cdot \mathrm{LL}$ & $25.07 \pm 0.33$ & $27.72 \pm 0.34^{\text {al }}$ & $27.82 \pm 0.35^{\text {a1 }}$ \\
$600 \mathrm{mg} / \mathrm{kg} \cdot \mathrm{LL}$ & &
\end{tabular}

The result is expressed as mean \pm standard error of the mean, $n=6$; ${ }^{a}$ compared to diabetic control; ${ }^{1} p<0.01 ;{ }^{2} p<0.001$. BW, body weight; DC, diabetic control; LL, leaf latex; NC, normal control.

In this study, the leaf latex of A. pulcherrima showed concentration-dependent antioxidant activity in DPPH assay. This finding is concordat with free radical scavenging activities of the latex of Aloe schelpei, Aloe megalacantha, and Aloe monticola in DPPH assay [25,34,39]. Oxidative stress is a decisive factor in the pathogenesis of diabetes mellitus. Reactive oxygen species act as a second messenger that
TABLE 6: The effect of the leaf latex of Aloe pulcherrima on serum lipid level in diabetic mice.

\begin{tabular}{|c|c|c|c|}
\hline \multirow{2}{*}{ Groups } & \multicolumn{3}{|c|}{ Serum lipid level } \\
\hline & $\mathrm{TC}$ & TG & HDL-C \\
\hline $\begin{array}{l}10 \mathrm{ml} / \mathrm{kg} \\
\text { vehicle NC }\end{array}$ & $88.50 \pm 5.86$ & $96.83 \pm 5.86$ & $38.83 \pm 1.49$ \\
\hline $\begin{array}{l}10 \mathrm{ml} / \mathrm{kg} \\
\text { vehicle DC }\end{array}$ & $187.17 \pm 2.44$ & $175.83 \pm 2.97$ & $26.67 \pm 2.02$ \\
\hline $\begin{array}{l}5 \mathrm{mg} / \mathrm{kg} \\
\text { glibenclamide }\end{array}$ & $94.50 \pm 2.09^{\mathrm{a} 3 \mathrm{~b} 1}$ & $105.76 \pm 7.80^{\mathrm{a} 3 \mathrm{~b} 1}$ & $37.67 \pm 0.71^{\mathrm{a} 3}$ \\
\hline $200 \mathrm{mg} / \mathrm{kgvLL}$ & $179.00 \pm 1.71^{\mathrm{alcl}}$ & $154.33 \pm 2.65^{\mathrm{a} 1 \mathrm{cl}}$ & $34.17 \pm 1.08^{\mathrm{b} 2}$ \\
\hline $400 \mathrm{mg} / \mathrm{kg} \cdot \mathrm{LL}$ & $178.33 \pm 1.58^{\mathrm{a} 2}$ & $154.17 \pm 1.51^{\mathrm{a} 2}$ & $34.33 \pm 1.15^{\mathrm{b} 2}$ \\
\hline $600 \mathrm{mg} / \mathrm{kg} \cdot \mathrm{LL}$ & $178.30 \pm 1.02^{\mathrm{a} 2}$ & $153.33 \pm 4.34^{\mathrm{a} 2}$ & $36.67 \pm 0.71^{\mathrm{b} 2}$ \\
\hline
\end{tabular}

Values are expressed as mean \pm standard error of the mean, $n=6$; ${ }^{a}$ compared to diabetic control; ${ }^{b}$ to $200 \mathrm{mg} / \mathrm{kg}$; ${ }^{c}$ to $5 \mathrm{mg} / \mathrm{kg} .{ }^{1} p<0.05$; ${ }^{2} p<0.01 ;{ }^{3} p<0.001$. DC, diabetic control; HDL-C, high-density lipocholestrol; NC, normal control; LL, leaf latex; TC, total cholesterol; TG, triglyceride.

activates nuclear factor kappa B (NF- $\kappa$ B), necrosis factor- $\alpha$ (TNF- $\alpha$ ), and interleukins (ILs) which reduces the expression of GLUT 4 and activates intracellular adhesion molecule-1 to stimulate the growth of insulin resistance [40-43]. Therefore, preventing oxidative stress might be one 
approach to reduce onset of diabetes and its complications $[24,43,44]$. Antioxidants, such as $\alpha$-lipoic acid, ubiquinone, and flavonoids prevent diabetic onset and ameliorate its complications $[43,45]$.

The leaf latex of $A$. pulcherrima showed sucrase, maltase, and $\alpha$-amylase inhibitory effects. Enzyme inhibition capacity of the latex was concentration dependent, and greater inhibition was observed on sucrase $\left(\mathrm{IC}_{50}=2.92 \mu \mathrm{g} / \mathrm{ml}\right)$ relative to maltase $\left(\mathrm{IC}_{50}=11.81 \mu \mathrm{g} /\right.$ $\mathrm{ml})$ and $\alpha$-amylase $\left(\mathrm{IC}_{50}=14.92 \mu \mathrm{g} / \mathrm{ml}\right)$ enzymes. This result is in line with concentration dependent $\alpha$-amylase inhibitory effect of the leaf latex and isolated compounds of Aloe megalacantha and Aloe monticola [25]. The successful prevention or control of postprandial hyperglycemia is through inhibition of $\alpha$-glucosidase and $\alpha$-amylase, [26] since these enzymes facilitate carbohydrate digestion and absorption. $\alpha$-Glucosidase is the most important enzyme for digestion and absorption of starch and sucrose [2, 24]. Modern $\alpha$-glucosidase and $\alpha$-amylase inhibitors have limited efficacy and induces deleterious effects [24, 25]. Therefore, plant-derived bioactive molecules may serve as novel alternatives in postprandial glycemic control.

Enzyme inhibitory effect of the latex calls for further investigation in normoglycemic, oral glucose-loaded, and streptozotocin-induced diabetic mice. Measuring blood glucose level was the most reliable parameter in all models. Body weight and serum lipid level were evaluated in the streptozotocin-induced diabetic model [24, 36].

The low dose of $(200 \mathrm{mg} / \mathrm{kg})$ the latex significantly $(p<0.05)$ induced hypoglycemia after $4 \mathrm{~h}$, but did not sustain the effect for $6 \mathrm{~h}$ possibly due to early elimination from body. The medium and high doses of the latex brought significant hypoglycemia after $4 \mathrm{~h}$ and $6 \mathrm{~h}$ in the normoglycemic model. Hypoglycemic effect of glibenclamide was significant after 2, 4, and $6 \mathrm{~h}$. This indicated that the leaf latex and glibenclamide changed blood glucose level though the same mechanism of action (increased insulin release or insulin-like effect). This finding is concordant with significant hypoglycemic effect of the leaf gel of Aloe vera and the latex of A. megalacantha in the normoglycemic model $[34,46]$. Aloe species contain poly and monosaccharides that play blood glucose reduction by increasing insulin level, and hence, the plants show hypoglycemic activities $[47,48]$.

In this study, medium and high doses of the latex significantly $(p<0.001)$ reduced blood glucose level after one and two hours of oral glucose loading in the glucose tolerance test. Glucose reducing effect of the low dose was delayed and significant $(p<0.01)$ after two hours. The result showed that medium and high doses of the latex had fast onset and greater glucose reduction. This is comparable with significant postprandial glucose reducing effect of the leaf latex of Aloe megalacantha [34].

Administration of the latex for two weeks to STZinduced diabetic mice showed prominent blood glucose reducing compared to diabetic control. Glucose reduction effect was increased with increasing the doses of the leaf latex of $A$. pulcherrima $(p<0.05,200 \mathrm{mg} / \mathrm{kg} ; p<0.01$,
$400 \mathrm{mg} / \mathrm{kg}$; and $p<0.001,600 \mathrm{mg} / \mathrm{kg}$ on week one), indicating that low and medium doses of the latex had less cummulative effect on week one. Thus, cummulative glucose reduction with the latex was time and dose dependent $(p<0.01$, low dose, and $p<0.001$, medium and high dose on week two). The relative variation in blood glucose reduction among doses might be due to variation of the amount of secondary metabolite content in the leaf latex of Aloe pulcherrima. The findings showed that the plant was endowed with glucose lowering potential, and the effect was concordant with dose-dependent antidiabetic activity of the leaf latex of Aloe megalacantha [34]. In another study, administration of Aloe vera leaf gel at the doses of 200 and $400 \mathrm{mg} / \mathrm{kg}$ has been safe and effective as $50 \mathrm{mg} / \mathrm{kg}$ metformin [13]. Currently available antidiabetic agents contraindicated in renal and hepatic failure diabetic patients $[14,16]$. Aloe vera leaf gel showed protective effect on diabeticinduced renal and liver damage, and hence, leaf gel of the plant and its derivative might be preferable in comorbid diabetic patients $[13,49]$.

In this study, significant BW increment was measured in diabetic mice treated with all doses of the leaf latex of A. pulcherrima and glibenclamide in STZ-induced diabetic mice. Compared to diabetic control, BW of the mice treated with all doses of the latex remarkably increased on week one and two. The study result indicated that the latex was endowed with preventive effect against diabetic-induced body weight loss.

Induction of diabetes by streptozotocin significantly elevated total cholesterol (TC) and triglycerides (TG) while decreasing high-density lipoprotein (HDL-C) compared to normal control. After two weeks of intervention with the leaf latex of $A$. pulcherrima, the lipid level of diabetic mice was significantly improved compared to diabetic control. All doses of the latex significantly reduced the levels of TC and TG, and increased the level of HDL-C. Thus, the latex of Aloe pulcherrima might serve as the potential candidate in the treatment of hyperglycemia induced dyslipidemia. The current result is in line with antidyslipidemic activity of the leaf of Aloe vera and Aloe megalacantha in STZ diabetic rodents $[34,48]$.

The finding showed that antidiabetic activity of the leaf latex of Aloe pulcherrima was statistically significant. Medium and higher doses of the latex showed comparable antidiabetic and antidyslipidemic activities with glibenclamide. Therefore, Aloe pulcherrima might serve as potential source for the development of the novel plantbased antidiabetic agents.

Flavonoids, glycosides, alkaloids, terpenoids, and others were present in the leaf latex of Aloe pulcherrima and have shown antidiabetic and antidyslipidemic activity in various plant extracts $[9,11,13,24,30,34,50]$. Many bioactive compounds isolated from Aloe species have sugar moiety and structurally resemble with glucose which is a key factor for insulin release [51]. Therefore, hypoglycemic, antihyperglycemic, and antidyslipidemic activities of the leaf latex of Aloe pulcherrima is possible due to a single or combined action of phytochemicals. 


\section{Conclusion}

The result showed that the leaf latex of Aloe pulcherrima was endowed with a prominent blood glucose reducing effect. This finding offers a clue for the development of safe and effective herbal formulation to treat diabetes mellitus. Consequently, further study is required for characterization and isolation of bioactive compounds that have antidiabetic effect.

\section{Abbreviations}

EPHI: Ethiopian Public Health Institute

GLUT 4: Glucose transporter 4

TC: Total cholesterol

TG: Triglycerides.

\section{Data Availability}

All the datasets used or analyzed during the present study are available from the corresponding author on reasonable request.

\section{Ethical Approval}

The study was carried out according to the Organization for Economic Cooperation and Use of Laboratory Animals' guidelines. The ethical review committee of Wollo University approved the study.

\section{Conflicts of Interest}

The authors declared that they do not have any conflicts of interest.

\section{Authors' Contributions}

Gedefaw Getnet Amare, Birhanu Geta Meharie, and Yaschilal Muche Belayneh designed the study, conducted the experiment, analyzed the data, and wrote the results. Gedefaw Getnet Amare prepared the manuscript and submitted approved version of the manuscript.

\section{Acknowledgments}

The authors are thankful to Wollo University for funding the study. The authors are also grateful to Professor Sebsebe Demisew for identification and authentication of the study plant.

\section{References}

[1] S. Edwards, I. Da-Costa-Rocha, M. J. Lawrence, C. Cable, and M. Heinrich, "Use and efficacy of herbal medicines: part 1historical and traditional use," Acute Pain, vol. 10, 2019.

[2] H.-Y. Hung, K. Qian, S. L. Morris-Natschke, C.-S. Hsu, and K.-H. Lee, "Recent discovery of plant-derived anti-diabetic natural products," Natural Product Reports, vol. 29, no. 5, pp. 580-606, 2012.

[3] H. M. Kitua AYM, "Malaria control in Africa and the role of traditional medicine," in Traditional Medicinal Plants and
Malaria, M. Willcox, G. Bodeker, P. Rasoanaivo, and J. Addae-yereme, Eds., CRC Press, Boca Raton, FL, USA, 1st edition, 2004.

[4] B. Hawkins, Plants for Life Medicinal Plant Conservation and Botanic Gardens, BGCI, Richmond, UK, 2007.

[5] S. Li, W. Yuan, P. Yang et al., "Pharmaceutical crops: an overview faculty publications," 2010, https://scholarworks. sfasu.edu/agriculture_facultypubs/4.

[6] F. Y. N. Yousef, O. Mansour, and J. Herbali, "Metformin: a unique herbal origin medication," Global Journal of Medical Research, vol. 17, no. 3, 2017.

[7] S. C. B. Bhavna S Rajani, "Anti-diabetic potential of alkaloid rich fraction from capparis decidua on diabetic mice," Journal of Ethnopharmacology, vol. 127, pp. 457-462, 2010.

[8] J. K. Y. S. Grover and V. Vats, "Medicinal plants of India with antidiabetic potential," Journal of Ethnopharmacology, vol. 81, pp. 81-100, 2002.

[9] A. Mollica, G. Zengin, M. Locatelli et al., "Anti-diabetic and anti-hyperlipidemic properties of capparis spinosa L.: in vivo and in vitro evaluation of its nutraceutical potential," Journal of Functional Foods, vol. 35, pp. 32-42, 2017.

[10] A. Mollica, A. Stefanucci, G. Macedonio et al., "Chemical composition and biological activity of capparis spinosa L. from lipari Island," South African Journal of Botany, vol. 120, pp. 135-140, 2019.

[11] A. Mollica, G. Zengin, M. Locatelli et al., "An assessment of the nutraceutical potential of juglans regia L. leaf powder in diabetic rats," Food and Chemical Toxicology, vol. 107, pp. 554-564, 2017.

[12] M. B. Abo-Youssef AMH, "Beneficial effects of aloe vera in treatment of diabetes: comparative in vivo and in vitro studies," Bulletin of Faculty of Pharmacy, Cairo University, vol. 51, no. 1, pp. 7-11, 2013.

[13] H. F. Huseini, S. Kianbakht, R. Hajiaghaee, and F. H. Dabaghian, "Anti-hyperglycemic and antihypercholesterolemic effects of aloe vera leaf gel in hyperlipidemic type 2 diabetic patients: a randomized double-blind placebo-controlled clinical trial," Planta Medica, vol. 78, no. 04, pp. 311-316, 2012.

[14] C. Varas-Lorenzo, A. V. Margulis, M. Pladevall et al., "The risk of heart failure associated with the use of noninsulin blood glucose-lowering drugs: systematic review and meta-analysis of published observational studies," BMC Cardiovascular Disorders, vol. 14, no. 1, p. 129, 2014.

[15] S. K. Bharti, S. Krishnan, A. Kumar, and A. Kumar, "Antidiabetic phytoconstituents and their mode of action on metabolic pathways," Therapeutic Advances in Endocrinology and Metabolism, vol. 9, no. 3, pp. 81-100, 2018.

[16] D. Tschöpe, M. Hanefeld, J. J. Meier et al., "The role of comorbidity in the selection of antidiabetic pharmacotherapy in type-2 diabetes," Cardiovascular Diabetology, vol. 12, no. 1, 10 pages, 2013.

[17] CCW, "Aloe pulcherrima-a beautiful ethiopian endemic," Cactus World, vol. 35, no. 2, pp. 131-135, 2017.

[18] T. Teka, D. Bisrat, M. Y. Yeshak, and K. Asres, "Antimalarial activity of the chemical constituents of the leaf latex of Aloe pulcherrima gilbert and sebsebe," Molecules, vol. 21, no. 11, p. $1415,2016$.

[19] D. Abdissa, G. Geleta, K. Bacha, and N. Abdissa, "Phytochemical investigation of Aloe pulcherrima roots and evaluation for its antibacterial and antiplasmodial activities," PloS One, vol. 12, no. 3, Article ID e0173882, 2017.

[20] A. Enyew, Z. Asfaw, E. Kelbessa, and R. Nagappan, "Ethnobotanical study of traditional medicinal plants in and 
around Fiche District, Central Ethiopia," Current Research Journal of Biological Sciences, vol. 6, no. 4, pp. 154-167, 2014.

[21] M. Wubetu, T. Abula, and G. Dejenu, "Ethnopharmacologic survey of medicinal plants used to treat human diseases by traditional medical practitioners in dega Damot district, Amhara, Northwestern Ethiopia," BMC Research Notes, vol. 10, no. 1, p. 157, 2017.

[22] W. P. Jones and A. D. Kinghorn, Extraction of Plant Secondary Metabolites: Natural Products Isolation, Springer, Berlin, Germany, 2012.

[23] A. Pandey and S. Tripathi, "Concept of standardization, extraction and pre phytochemical screening strategies for herbal drug," Journal of Pharmacognosy and Phytochemistry, vol. 2, no. $5,2014$.

[24] A. Toma, E. Makonnen, Y. Mekonnen, A. Debella, and S. Adisakwattana, "Antidiabetic activities of aqueous ethanol and $n$-butanol fraction of Moringa stenopetala leaves in streptozotocin-induced diabetic rats," BMC Complementary and Alternative Medicine, vol. 15, no. 1, p. 242, 2015.

[25] G. H. Tekulu, E. M. Araya, and H. G. Mengesha, "In vitro $\alpha$-amylase inhibitory effect of TLC isolates of aloe megalacantha baker and aloe monticola reynolds," BMC Complementary and Alternative Medicine, vol. 19, no. 1, p. 206, 2019.

[26] S. Adisakwattana, T. Ruengsamran, P. Kampa, and W. Sompong, "In vitro inhibitory effects of plant-based foods and their combinations on intestinal $\alpha$-glucosidase and pancreatic $\alpha$-amylase," BMC Complementary and Alternative Medicine, vol. 12, no. 1, p. 110, 2012.

[27] W. Tamiru, E. Engidawork, and K. Asres, "Evaluation of the effects of $80 \%$ methanolic leaf extract of caylusea abyssinica (fresen.) fisch. \& mey. on glucose handling in normal, glucose loaded and diabetic rodents," BMC Complementary and Alternative Medicine, vol. 12, no. 1, p. 151, 2012.

[28] P. Vital, E. Larrieta, and M. Hiriart, "Sexual dimorphism in insulin sensitivity and susceptibility to develop diabetes in rats," Journal of Endocrinology, vol. 190, no. 2, pp. 425-432, 2006.

[29] M. Deeds, J. Anderson, A. Armstrong et al., "Single dose streptozotocin-induced diabetes: considerations for study design in islet transplantation models," Laboratory Animals, vol. 45, no. 3, pp. 131-140, 2011.

[30] F. F. Yanyan Zhang, T. Chen, Z. Li, W. Qingwu, and Shen, "Antidiabetic and antihyperlipidemic activities of forsythia suspensa (thunb.) vahl (fruit) in streptozotocin-induced diabetes mice," Journal of Ethnopharmacology, vol. 192, no. 256, pp. 256-263, 2016.

[31] M. Z. B. Yaschilal, M. Eshetie, and G. Gedefaw, "Evaluation of in vivo antidiabetic, antidyslipidemic and in vitro antioxidant activities of hydromethanolic root extract of Datura stramonium L. (solanaceae)," Journal of Experimental Pharmacology, vol. 11, pp. 29-38, 2019.

[32] M. S. Demoz, K. P. Gachoki, K. J. Mungai, and B. G. Negusse, "Evaluation of the anti-diabetic potential of the methanol extracts of aloe camperi, meriandra dianthera and a polyherb," Journal of Diabetes Mellitus, vol. 5, no. 04, p. 267, 2015.

[33] A. J. King, "The use of animal models in diabetes research," British Journal of Pharmacology, vol. 166, no. 3, pp. 877-894, 2012.

[34] W. W. Hammeso, Y. K. Emiru, K. Ayalew Getahun, and W. Kahaliw, "Antidiabetic and antihyperlipidemic activities of the leaf latex extract of aloe megalacantha baker (aloaceae) in streptozotocin-induced diabetic model," Evidence-Based
Complementary and Alternative Medicine, vol. 2019, Article ID 8263786, 189 pages, 2019.

[35] J. E. F. Z. Bowe, A. C. Hauge-Evans, A. J. King, S. J. Persaud, and P. M. Jones, "Metabolic phenotyping guidelines: assessing glucose homeostasis in rodent models," Journal of Endocrinology, vol. 222, no. 3, pp. G13-G25, 2014.

[36] Y. M. Belayneh, E. M. Birru, and D. Ambikar, "Evaluation of hypoglycemic, antihyperglycemic and antihyperlipidemic activities of $80 \%$ methanolic seed extract of calpurnia aurea (Ait.) Benth.(fabaceae) in mice," Journal of Experimental Pharmacology, vol. 11, p. 73, 2019.

[37] S. Sharma, M. Choudhary, S. Bhardwaj, N. Choudhary, and A. C. Rana, "Hypoglycemic potential of alcoholic root extract of cassia occidentalis linn. in streptozotocin induced diabetes in albino mice," Bulletin of Faculty of Pharmacy, Cairo University, vol. 52, no. 2, pp. 211-217, 2014.

[38] H. G. Vogel and W. H. Vogel, Drug Discovery and Evaluation: Pharmacological Assays, Springer Science \& Business Media, Berlin, Germany, 2013.

[39] H. K. Tekleab Teka, "Characterization and evaluation of antioxidant activity of Aloe schelpei Reynolds," Drug Design, Development and Therapy, vol. 14, pp. 1003-1008, 2020.

[40] J. S. B. G. Skyler, E. Bonifacio, T. Darsow, R. H. Eckel, L. Groop et al., "Differentiation of diabetes by pathophysiology, natural history, and prognosis," Diabetes, vol. 66, no. 2 , pp. 241-255, 2017.

[41] P. A. R. G. Gerber, "The role of oxidative stress and hypoxia in pancreatic beta-cell dysfunction in diabetes mellitus," Antioxidants \& Redox Signaling, vol. 26, no. 10, pp. 501-518, 2017.

[42] O. U. S. Jeremiah and L. Lucky, "Antioxidant effects and mechanisms of medicinal plants and their bioactive compounds for the prevention and treatment of type 2 diabetes: an updated review," Oxidative Medicine and Cellular Longevity, vol. 2020, Article ID 1356893, , 2020.

[43] R. G. V. Luis Miguel, D. Adolfo, G. Alejandra et al., "Diabetic polyneuropathy in type 2 diabetes mellitus: inflammation, oxidative stress, and mitochondrial function," Journal of Diabetes Research, vol. 2016, p. 16, 2016.

[44] R. N. S. Rahimi, B. Larijani, and M. Abdollahi, "A review on the role of antioxidants in the management of diabetes and its complications," Biomed Pharmacother, vol. 59, pp. 365-373, 2005.

[45] B. A. O. Ayodeji, M. Emmanuel, and M. Bubuya, "Antioxidant strategies in the management of diabetic neuropathy," BioMed Research International, vol. 2015, p. 15, Article ID 515042, 2015.

[46] S. G. D. Lanjhiyana, D. Ahirwar, A. C. Rana, B. Ahirwar, and S. K. Lanjhiyana, "Pharmacognostic standardization and hypoglycemic evaluations of novel polyherbal formulations," Der Pharmacia Lettre, vol. 3, no. 1, pp. 319-333, 2011.

[47] S. A. Bahare Salehi, A. Hubert, D. Kr ‘ egiel et al., "Aloe genus plants: from farm to food applications and phytopharmacotherapy," International Journal of Molecular Science, vol. 19, p. 2843, 2018.

[48] A. K. Monika Choudhary and J. Sangha, "Hypoglycemic and hypolipidemic effect of aloe vera L. in non-insulin dependent diabetics," Journal of Food Science and Technology, vol. 51, no. 1, pp. 90-96, 2014.

[49] Y. S. H. Akira, K. Amal, and W. Engy Abd-El, "Possible hypoglycemic effect of aloe vera L. high molecular weight fractions on type 2 diabetic patients," Saudi Pharmaceutical Journal, vol. 17, pp. 209-215, 2009. 
[50] E. Janda, A. Lascala, C. Martino et al., "Molecular mechanisms of lipid-and glucose-lowering activities of bergamot flavonoids," Pharma Nutrition, vol. 4, pp. S8-S18, 2016.

[51] E. Dagne, D. Bisrat, A. Viljoen, and B. Van Wyk, "Chemistry of aloe species," Current Organic Chemistry, vol. 4, no. 10, pp. 1055-1078, 2000. 